\title{
Anthrovision
}

Vaneasa Online Journal

1.2 | 2013

Varia

\section{Is watching the feast making the feast?}

Visual language and practice in an ethnography

\section{Katia Ballacchino}

\section{(2) OpenEdition \\ Journals}

Electronic version

URL: http://journals.openedition.org/anthrovision/586

DOI: 10.4000/anthrovision.586

ISSN: 2198-6754

Publisher

VANEASA - Visual Anthropology Network of European Association of Social Anthropologists

\section{Electronic reference}

Katia Ballacchino, "Is watching the feast making the feast? », Anthrovision [Online], 1.2 | 2013, Online since 01 August 2013, connection on 20 April 2019. URL : http://journals.openedition.org/ anthrovision/586; DOI : 10.4000/anthrovision.586

This text was automatically generated on 20 April 2019.

(c) Anthrovision 


\title{
Is watching the feast making the feast?
}

\author{
Visual language and practice in an ethnography
}

\author{
Katia Ballacchino
}

1 This article is an experimental meditation on an ongoing work on the visual dimension of on the Gigli. This one hundred year-old feast takes place annually in Nola, near [?] Naples, in the Campagna region of southern Italy. The analysis of this event started as a visual ethnography, a meeting point between the researcher's modality of "watching" with that of the investigated protagonists, which include the hundreds of men who carry imposing ritual structures on the day of the feast. ${ }^{1}$ It argues that the use of videocamera is essential to achieving the objectives of long-term ethnographic research. Furthermore, the camera legitimates the researcher's access to the community under investigation, from field work to the construction of knowledge itself. Issues concerning vision and knowledge through images are at the centre of contemporary scientific debates, making the development of analytical approaches to the modalities of watching a key challenge for anthropological disciplines ${ }^{2}$. The literature on visual anthropology ${ }^{3}$ questions issues related to the methodology of visual ethnography and precisely from the main questions on the multiplicity of looks and the positioning of the researcher this article will produce some remarks.

2 The argument that visual research can produce results central to ethnographic knowledge through collaborative and participative methods had already been suggested by Rouch in the 1970's. Through the process of feedback, he observed that a researcher could collect a larger number of data by reviewing the filmed material with informers than what he could collect through months of direct observation and interviews. In the light of this, this article proposes a horizontal perspective of sharing of the interaction between different experiences and multiple voices; a sort of "polyphonic anthropology", a tendency to interact with the investigated subjects in the framework of a collaborative analysis, based on the functional use of the video camera. In other words, an anthropological analysis will assume political value through a visual methodology that attends to observable details of the ritual as well as the perspectives of the protagonists, including the anthropologist. 
3 My analysis uses what Grasseni has defined as an ethnographic model "of observation", derived from documentary or observational filmmaking and suited to exploring aspects of ability, technique and knowledge of daily practices. ${ }^{4}$ This requires the most "intimate" gaze possible. Being experienced from the inside, it allows participant observation through the video camera to become part of a process of daily discovery of the context itself. This leads to the possibility of exploring a certain "vision of the world" that is connected to a specific ability to "see" and also to hear, move, speak, understand ourselves and, finally, to the possibility of understanding a documentary (or, at any rate, a video product) as the fruitful integration of ethnographic writing, producing a polyphonic documentary and giving voice to the many characters rather than to the anthropologist only.

Drawing on research carried out between 2006 and 2011, this article argues for the centrality of the ethnographic work in the investigation of the most innovative field for contemporary anthropology: visual culture. The original characteristics of this feast makes it "good to think with" (ref Levi-Strauss) in visual anthropological terms, and leads to a hypothesis about the potential of the visual as a methodology and metaphor of anthropology. Beginning with concrete [?] ethnographic examples, the article presents communal ritual practice through three visual dimensions: as a methodological and knowledge-producing practice of investigation, as the object and source of the research itself and, lastly, the visual document as a potential product of ethnography alongside the written text.

5 Therefore this article will try to answer some questions in anthropological literature about visual apprenticeship and the methodological role of the participant observation. How does the video camera contribute to the internal observation of the investigated community as a methodology of apprenticeship? How can the ethnographer engage in a worthwhile dialogue by means of a visual product and give back the production of a knowledge to the investigated community, alternate or parallel to the result achievable by means of writing? Can this practice be useful not only in the investigated community but also in the didactic use of the images produced during the ethnographic research, or in the confrontation internal to the scientific debate? Is it possible to consider the products of a work of visual documentation as a modality similar to the reading of a field diary, to support the drafting of the written work? Lastly, is it possible for anthropology to attribute a political value to the modality of watching and of watching oneself? These are the questions this article will attempt to address, through the data provided by the same ethnography..

\section{When the field determines the methods: images of the Gigli Feast of Nola}

6 My research was based in Nola, the city where the Gigli feast has been celebrated every year for centuries, moving through the streets of the historical center in a procession of nine ceremonial constructions: eight twenty-five meter-tall obelisks (paranza) ${ }^{5}$ or gigli ("lily flower"), and a boat, which are built each year out of wood and paper-maché. The feast is held on the Sunday after 22 June, the patronal feast of Saint Paulinus. ${ }^{6}$ On that day, each obelisk is carried on the shoulders of a group of hundreds of men, the lifters for approximately 24 hours, to the sound of music (fig. 1) 
7 Over six years I have conducted a longitudinal ethnographic study. Extended periods of residence in the field site(S?) have involved the daily construction of a rich network of relations which have enabled me to research in depth the hundreds of individuals engaged in organizing the festival for the entire. Multiple "copies" of the gigli have also proliferated in various villages, reproducing Nolan activities and practices through the Campania region and beyond. For example, in the Williamsburg district of Brooklyn, a single giglio and a boat have been made to "dance" for over a century by Italian Americans living in New York and elsewhere. ${ }^{7}$ My research monitors these geographical dislocations of the feast to analyze the relationship between migration and the production of culture. The Gigli feast is understood as a practice that inserts the global dimension into the local context through its deep connection to the past and tradition but mainly thanks to its hybrid practices, changeability and drive to keep up with the times that render its character enduringly contemporary. The feast represents the most intimate and yet spectacular cultural expression of local identity, but across diverse geographic and historical-political contexts, it is also a set of changing and permeable traditional elements which produce conceptions of the world and relationships with outsiders. For local actors, it become a magnifying glass on the world, or what Durkheim would call a "total social fact" around which individuals narrate their own "cultural intimacy". ${ }^{8}$ Each time the feast is celebrated, participants strive to find an transforming contemporary identity and role, for themselves a "presence in the world" which changes over time and gains significance and different meanings as it travels.

Over the last few decades the "communities of practice" in various locations that celebrate the Gigli feast have experienced a process of visual hyper-documentation in the major media outlets, including television and especially on the internet. ${ }^{10}$. This has occurred furthermore within a setting marked by the visual documentation that has conditioned the feast's imaginary over time. In addition to numerous external researchers, local personnel and practitioners use cell phones and other recording devices to document every moment of the Gigli procession. This makes it possible to watch and re-watch the event, immediately on the internet and also during the rest of the year, so the festive atmosphere can be reproduced on demand in private homes and at public occasions. Therefore the feast can be understood not only an object being immortalized in images for the sake of its own aesthetic visual impact, but as a communicative need of those who want to transfer the festive atmosphere from ritual to other moments, thereby channeling emotions, relational dynamics and "world visions" (ref).

This explains why I chose to use a video camera during my research, not simply as a means of documentation, but as the principal means of relating to local protagonists. As is usual in anthropology, the territory and object of research imposed the necessity for a visual ethnography. "Watching the feast" and inscribing it visually has come to assume a value that to the community is similar to "making the feast" itself ; and some examples will be shown. 


\section{Watching and watching oneself: image, methodology, knowledge production}

\section{Inclusion and apprenticeship in "communities of practice"}

11 My work as a visual anthropologist originated in a critical re-interpretation of the classical concept of "festive time" as a ludic time that is separate from the everyday time of labor and work (ref.). In the case of the Gigli, my hypothesis is that the festive time represents a "totalizing time", and I chose to analyze visually and record the daily practices connected to the feast and beginning from these I investigated the creation of economic and political relations throughout the year: the invention of relational dynamics; the reinforcement of feelings; the production of disagreement; the activation of processes through which meaning is constantly renewed in the everyday; and the production of communities of practice that construct shared meanings and attribute a common significance to daily life, ${ }^{11}$ through their passion for the feast. This process could be defined as "legitimate peripheral participation", where learning is a consequence not only of teaching but also of the social practices acquired within a community. ${ }^{12}$

The meaning of Nolan practices emerges through the abilities of research participants but also the ethnographer herself have acquired in gaining knowledge of the local area and community. I revisit this classical anthropological issue of the role of the researcher in interpreting events, as a primarily visual "apprenticeship" which became a process of education, of relating, and of progressively inserting oneself into the communities of practice. ${ }^{13}$ The main investigative vector of ethnography is the "gaze", and the audiovisual dimension reveals itself to be invaluable when we consider the image to be a vehicle for conveying both cultural representations and emotions, especially in hyperdocumented and hyper-mediated contexts of ritual practice such as the Nolan Gigli.

Given the increasing consensus among contemporary anthropologists that the visual dimension plays a crucial role in ethnographic encounters with informants, I have tried to work simultaneously through and yet also on the visual world, maintaining a continuous dialogue between these two modes. Within the larger system of new technologies and media employed in research participants' daily practices, video (like photography) allows the ethnographer to uncover the social dimensions that are crucial for any specific ritual context. Thanks to the study, production and analysis of the use of images, elements such as body language, proxemics, kinesics, spatial composition, relations between individuals, identity-based self-representations, emotions, power relations, transformations, migrations, etc. turn out to be invaluable research areas, especially for a "multi-sited" ethnography.$^{14}$ According to Marcus (ref.), fieldwork begins from the analysis of a local site, which is then reconsidered by taking into account the macro-constructions of a wider social order so that the sites of observation and participation cross and investigate dichotomies such as for instance the decisive dichotomy of local/global.

It would be more appropriate to define my methodological approach as "multi-centered", an ethnography that employs different tools depending on the case, but focuses on a single festive institution in different physical and virtual spaces or "centers" of research. .These spatial dimensions reveal connections and trajectories that always return to a detailed analysis of the daily practices captured by images that can be traced to the 
"totalizing" festive system: a system of values, interpersonal relations and visions of the world. Participant observation of daily practices creates the conditions in which the ethnographer can access the "unspoken" elements of know-how, skills and experience. Such an "expert action" comprises a set of practical and knowledge-based abilities, rhythms and memories, ${ }^{15}$ and relations with various communities of practice. In this way the ethnographic method makes it possible to reveal tacit forms of knowledge, embodied skills and implicit modes of relating. Grasseni's "skilled vision", ${ }^{16}$ shared by a community of practice, gives shape and meaning to events from within the community, and it can also be shared by others if their gazes are disciplined and guided.

Re-reading de France, video recording in filmic anthropology can be understood as a process of insertion that includes a superficial and preliminary form of observation as well as a more profound form that only takes place through the repeated examination of the resulting images. The researcher's "insertion" mainly occurs on the moto-sensorial level through an identification of the rhythms and an awareness of the environment under investigation:

insertion consists of gaining the acceptance of the people being filmed - with or without a camera - and convincing them that it is in their interests to collaborate in the production of the film and the development of the inquiry. This means that the originality and success of the insertion phase are mainly about the moral and psychological quality of the relations that the filmmaker is able to establish with the people being filmed. ${ }^{17}$

Through this insertion, the visual ethnographer not only produces documentation but gains acceptance and recognition of the community,for her investigative role, and comes to understand the meaning of the research participants' gaze through a common language.

17 From the beginning of my research in Nola I noticed how much time throughout the year was invested in talking about or "collectively watching" video documents of the Gigli feast, and I inferred that participants attributed the utmost importance to visual language in relation to the feast. This is one reason why right from the beginning I felt the need to use a video camera in working on the life of the Nolan community. Indeed, there is an ever growing number of images produced about the Gigli feast every year, thanks in part to the frenetic use of web images by the younger generations who actively participate in the feast.

Thanks to technological shifts that have increased access to the means of production in the last decades,$^{18}$ rendering them ever lighter, more affordable and therefore easier to use, the production of amateur images has increased significantly ${ }^{19}$. Most recently, the latest generation of cellular phones has made it possible for users to easily "record" any scene they viewed or in which they participated. This has created an intense multiplication of points of view on both private and public events. Drawing on Rouch's reflections ${ }^{20}$ and approaching the festive scene as a phenomena crossed on every level by a "participating camera", in my work the use of a hand-held video camera turned out to be the best solution in terms of results, but also the most complicated in terms of physical effort. I was operating the video camera myself in conditions that were made very difficult by the heat and crowds, and so the participants were obliged to completely accept my presence in order for me to be able to "live" the feast from within as much as possible. They were required to protect me and the video camera from the difficulties and 
dangers represented by the tumultuous passage of hundreds of people thronging under their Giglio along the ritual path for twenty four hours (fig. 2).

\section{From the field ...on learning to watch the Gigli}

Despite months of preliminary investigations and attempts to become acquainted with the protagonists, my true and substantial inclusion in the community of practice began on the day of the feast, when the "Fantastic Team" or "FT" paranza (fig. 3) I had chosen to work with then began to "take care" of me and my video recording of the feast, even in the most hazardous sections of the ritual path. For instance, in 2007, in a narrow stretch that was particularly difficult for the collective transportation of the obelisk, ${ }^{21}$ a bearer who was taking a temporary break from carrying the giglio positioned himself to give me the best possible shot. He also protected me from the attacks of the crowd in the narrow street where the obelisk needed to pass, creating a space around me so that I would not be crushed or swept away. It was necessary for me to carry out a delicate operation of walking backwards with the video camera to hold focus on the Giglio as it made its imposing advance.

When you walk down perilous paths, you need to be guided: I have often hit my head and broken cables or lenses simply because there was a rock I had not seen; for this reason the operator needs to be guided by someone, especially when walking backwards (Rouch 1981: 44). [ ${ }^{22}$ cut note]

Without my research subject's expectation of my action, I would not have been able to film such a complicated scene; I would not have obtained a firm support behind my mobile filming position; and I would have not been able to film that complicated, crucial scene. At that particular moment I gained a much greater understanding of "how" to look at the Giglio and about the Giglio itself than I had acquired through the rest of the year during dozens of hours of conversations and stories about this ritual climax. It was also at that precise moment that I achieved a full acceptance of my role in the group. Because this occurred while I was filming as part of the festive scene, it was also a real moment of being educated in the appropriate gaze for the Giglio in motion. The subsequent process of watching the video product of the feast together with practitioners also proved to be a precious moment of "education" in the community of practice's shared gaze.

After-the-fact observation allows the analyst of the image to develop his or her understanding of the process being observed, thanks in part to the potential for infinite repetition. ${ }^{23}$

In Nola, copious use is made of video and photographic reproductions in the multiple festive moments that occur throughout the year and are thus not limited to the feast day itself. I myself chose to share many of the numerous hours of footage (filmed in Nola, New York and elsewhere) with the people who participated in the recorded ritual scenes. This operation turned out to be an invaluable ethnographic "practice" that enabled me to gather further data about the daily life of the Nolan community in relation to the ritual, its "embodiment", ${ }^{24}$ and the more internal aspects of the city's emotional system, data which would otherwise have remained obscure to an external gaze. Within the community of "Gigli-ist" practices, as locals call them, acquiring the ability to develop a "good eye" for the construction of a Giglio or the composition and performance of a paranza is unseparable from a close daily relationship with the practitioners. Grasseni has also highlighted de France's insights into the apprenticeship of the gaze: 
When I began to film the process of evaluating genetically selected chiefs, I became particularly aware that I did not know how to look at them. On the other hand, I started to obtain good footage when I learned to acquire a certain method of looking. The video camera therefore functioned as a catalyst of attention. ${ }^{25}$ it immediately triggered an unprecedentedly ex I had recorded the scene (and by extension the feast itself), using the expert terms exclusive to "insiders". My recording failed to follow the musical rhythm of the Giglio that corresponds to specific movements on the part of the paranza, which I had still not learned to decipher in terms of visual equivalents. Some scenes in my video demonstrated to them that I had not learned how to move "properly" through the crowd or how to capture subtle nuances of the ritual practice that are fundamental to the expert eye of an insider. Elicitation generated a critique of the direction of the "gaze" that I shared with the participants that turned out to be a crucial method for understanding "their" gaze on themselves and on the ritual. It was also crucial for conducting the apprenticeship that is a part of any visual fieldwork methods and experience.. Indeed, it was often the participants themselves who protected my arm from the momentary violent chaos when I was at risk of falling or when the crowd violently forced me to move so I would not be crushed, to allow me to get the best shots. For the people of Nola, getting the best footage of the feast does not mean having a perfect framing technique or obtaining the most aesthetically pleasing footage, etc; rather, it means knowing what, how and when to shoot (fig. 4).

crete example is the moment when the obelisk is about to come to a halt and the capoparanza (the head of the paranza) gives the order to set the Giglio down with the ritual command cuonce cuonce e ghie' ("slow, slow and [put it] down"), you have to immediately understand from the precise musical note that in a few seconds the Giglio will stop moving and be set down; it is therefore necessary to immediately frame the top of the obelisk, to see if the statue stands erect or if it tends to sway, showing that the paranza is not apparata, that is, the group of bearers is not as homogeneously distributed as it should be. There is an implicit rule according to which one should film the moving Giglio until it is set down, or at least as long as it continues to dance within the frame, without turning the camera off or moving it to follow the obelisk, thus giving a sense that the Giglio is sinuously moving in relation to the fixed lens.

In this sense, De France's filmic anthropology offers an ethnographic method for analyzing the practices of a local context, as with exploratory film. The difference was that in my case it was not the initial aim (or at any rate, not the only aim) to produce a film about the Gigli; rather, I intended to conduct a profound analysis of the feast and the community itself. In order to investigate the communities of practice and the dimensions of meaning construction, it was therefore necessary to learn how to look, to hone my own focus on the details and the subjects' human experiences. As I experienced from the very beginning in Nola, the subjects themselves were able to recognize ethnographic authority or, at any rate, accept the insertion of the ethnographer into the group, often on the basis of a shared consensus about the modality though which they are "looked at". By the 
second year of recoding the ritual, the bearers themselves admitted that my videos were becoming ever more "Nolan" and from then on the group began to agree that the presence of my video camera was indispensable in every single festive moment. Throughout 2007, I followed the Nolan festive cycle for the first time, recording every public and private event. Thanks to my constant "exploratory" use of the video camera during these meetings, my presence started to become familiar as the months passed; however, at the same time, I was not completely camouflaged in that I clearly remained an observer of the most intimate local practices. Although on one hand this aided in valorizing my work in a masculine context where the role of a female ethnographer appeared to be ever more complex, on the other hand the ritual setting under investigation obviously risked being modified by the presence of an investigating camera lens capable of "judging" each practitioner's work. Little by little I thus became aware that I needed to take into account the fact that certain aspects of acquired knowledge might be modified by the presence of the video camera itself. Thanks to the long-term relations of reciprocity, empathy and trust I developed with the practitioners, as well as the familiarity granted to me by the passage of time and my constant presence over the years, this problem was gradually averted. Furthermore, until the actual feast days when I had to make concrete choices about "how" to look at and record the Giglio's dancing and the bearers' performance, everything I recorded was a simulation, merely "fictional" dancing by the obelisks; I therefore did not have the chance to understand how the "real" ritual scene would be. The above-mentioned problems began when I finally had to face not only the corporeal and linguistic narratives about the development of the feast, but also the actual Giglio dancing on the shoulders of the bearers. Eventually, however, I achieved such a full acceptance of my presence under the Giglio on the feast day that these days before the ritual performance of transportation begins, a participant uses the capoparanza's microphone to admonish onlookers to pay attention to me and my video camera and facilitate my movements around the paranza so that I could do my best work.

Another interesting aspect of this case is the competition triggered by the gaze of the recorded images. In Nola and elsewhere, the practice of gazing on one's own ritual performance in transporting the Gigli or the performances of other festive groups has come to represent a mode of socializing and reconfirming group belonging. During $\mathrm{m}$ years of ethnographic fieldwork in the competitive environment of Nola, I often watched video recordings of the performances of "adversary" paranze together with groups of bearers from a specific paranza. Witnessing how participants critiqued or judged the value or specific skills of the adversaries' capoparanza or bearers allowed me to see an equally rich process of identity construction linked to the shared practice of the feast; it revealed the sub-communities' dynamics of inclusion/exclusion and their mechanisms for granting or withholding recognition of "skills" used in the ritual performance.

Dozens of online groups have also emerged, born within the frames of various trendy virtual worlds, such as websites about the paranza and their respective discussion forums that function as "virtual piazzas" where the defects and merits of the feast are discussed every day. The internet additionally hosts channels for downloading music, photographic material and videos of the various Gigli feasts; there is even a Giglio in Second Life, built on the island dedicated to Napoli, complete with bearers and fans (fig. 5.). Furthermore, the Facebook virtual platform has been literally invaded by groups from Nola and elsewhere who are devotees of the Gigli feast. In other words, every virtual space used by the 
younger generations has become a site for focusing on the feast and interacting with others about the aspects that devotees hold most dear, all with the aid of images ${ }^{26}$.

\section{Between reality and ritual fiction, the ethnographer in an epoch of iper-mediatization}

It is useful at this point to describe some ethnographic episodes to illustrate the relationship that developed between me and the participants in relation to my work of researching and investigating through the video camera. In fact, with the passage of time my role became especially significant for those participants who wanted to publicly highlight their role and authority in the feast. These participants thought that, thanks to their visibility in my work (especially my visual work, given the immediate usability and long-lasting character of video), they would be imprinted in the memory of the feast, as was the case with some documents I will now analyze.

One exemplary episode occurred during the second year of my research and involved a Nolan informant in his mid-60's, a man who played a specific role in the feast: that of organizing one of the door-to-door fundraising campaigns in the rural areas surrounding Nola's historic center. His role as "head of the area" allowed him to enjoy a certain level of respect in the area where he lived. In fact, as described in the fieldnote extract included below, he asked me to record "his" ritual rounds to deliver committee shirts to participating families in exchange for economic offerings; since this ritual had already occurred a few days before when I was not able to attend, he re-staged the entire scene.

Today I had an appointment with C.F., who for days has been asking me to follow him on his rounds of distributing the shirts in his area, which are given out as a symbol of appreciation in exchange for the offerings that the families make during the collection campaign. $\mathrm{C}$. wanted me to use the video camera to record at least part of his rounds, which I wasn't able to record a few days ago. So, as we started our pilgrimage from house to house, I realized that he had alerted all the friends and relatives in the area that he would be coming by with me to record the ritual, which had actually already happened. I was amazed by the fact that he had "organized the entire scene" before having me turn on the camera; he talked with the families before giving them the shirts they had already received days ago, exchanging all the ritual greetings and courtesies that the moment required. (Extract from field notes.)

This episode illustrates how, a certain point in the research, my presence (especially as a visual documenter, in this case) became fundamental for those ritual moments considered most important; participants especially wanted to take part in the stories and images of the feast that I was documenting through my study. ${ }^{27}$. In this case, as in others I experienced, the role of the anthropologist becomes so central that a re-staging of the ritual comes to be invented for him or her. Once the anthropologist is granted legitimacy and "authority" to be on site, the informant decides that the researcher must be present or else the "scene" would not have the significance it warrants and a specific character would not have the role he deserves. In Nola, it is as if participants are constrained to "survive" a game of constant dialectics that reveal the strong individualism that also characterizes the city in other respects, as well as the irrational "collective passion" for the feast that functions to bind these conflictual dynamics and unite residents in a common desire to grant their Gigli and to the social "recognition" gained by being protagonists of the feast. 
31 In Nola, the visual dimension becomes a space of encounter with informants; paraphrasing Heraclitus, it is precisely in the attempt to better understand the language of the people under investigation that the visual dimension reveals itself to be, as in Nola, a true modality for dialogue, narrating and revitalizing the very memory of the community. As a matter of fact, there is an enormous amount of local video production about the feast. It is sufficient to note that the "master of the feast", whose role is to support a Giglio's feast for the entire year, commissions a photographer and cameraman for every Giglio (as you would for a wedding or other ceremony), who then produces a personalized video of the Giglio's entire festive performance. There are also photography and video shops that routinely capture the most important moments of each Giglio, specializing in shooting from various locations in the city, to then sell the resulting images to their many interested customers, not to mention the countless amateur videos shot during the course of the procession. In fact, this practice of shooting the feast in order to watch and re-watch them selves demonstrates how attached Nolan locals are to the details of their feast. I recall one comment that a capoparanza made during the dinner of his paranza group in 2008. He was observing the paradox of the moment we were all watching, a classic explosion of collective joy. The music of the Giglio was playing at a frantic rhythm and the young bearers were gathering at the center of the hall to celebrate by dancing the "typical" steps of the feast: a common action defined by the local expression Pazziare a fa o Giglio. ${ }^{28}$. The capoparanza noted that the majority of young men were more concerned with "filming" the event with their cell phones so they could post the images on YouTube or on the paranza website that same evening, than they were with experiencing the euphoria of the moment. This is undoubtedly a characteristic of today's younger generations, but in the case of the Gigli feast this kind of behavior is even more marked. Young people get together to watch the latest video posted on YouTube or certain specialized websites, in part to verify or to prove how many people took part in a specific Gigli-related event, thus how successful the event was. The videos often appear only a few hours after the event ends or even simultaneously as the event takes place, revealing the participants' anxiousness to be the first one to immediately watch them and make them public. In Nola, the "gaze" on the feast thus becomes a way of understanding reality, competition between groups and the social roles of practitioners in a very generalized way. It is also a means of stopping time and recording one's own cultural and local memory.

\section{The visual as object and source of analysis of locality}

32 In this historical moment, the feast exponentially reverberates the consequences of a visual hyper-documentation that mainly results from its contemporary media overexposure, and video documents hold an important place in the Nolan territory associated with the festive sphere. With this in mind, my research takes as one of its foci a critical study of visual sources, both local and non-local. Among the many documents I have analyzed, for this article it is useful to reference a document from the 1980s called La festa felice (The Happy Feast). ${ }^{29}$ The success that it has continued to enjoy over time demonstrates my conviction that the use of visual techniques and products can represent a truly productive source for critical analysis. ${ }^{30}$

33 La festa felice, a documentary made by director Gabriele Palmieri when he was working for the RAI Italian state television network, had a strong impact on the memory of Nolan 
residents and continues to be cited by ritual practitioners even today. ${ }^{31}$ This documentary is the product of many months of shooting conducted by the director and his crew in 1980. It consists of two parts: the first part uses voice-over commentary to recite extracts from the most well-known historical sources to describe the history of the saint, the feast and its origins, alongside images of the Gigli dancing on the feast Sunday morning. According to my analysis, many of the faces and names of the individuals starring in this video document have enjoyed increased "giglio-istic" fame around town thanks to this media exposure. In a way, it is the Nolan residents themselves who "direct" many researchers or feast enthusiasts toward the particular groups who are considered "winners" in the festive scene ${ }^{32}$. However, I believe that some of the most emblematic scenes from this film have in turn significantly contributed to granting certain actors an aura of prestige in the city's collective imaginary, thus making them "myths" of the feast's history. This is a result of the visual document's value, which succeeded in leaving such a tangible impression on the memory of the feast associated with that period in large part because it was the first product to give national visibility to the feast.

The video goes on to describe the Gigli's afternoon procession through the narrow streets of the city, one of the most competitive and exciting elements of the ritual. This is interspersed with extremely interesting interviews that broke new ground by interpolating actors such as the Bishop of Nola, and thereby addressing the Church's positioning in relation to the Gigli tradition. For example, the interviewer asks the sitting Bishop of the time about the delicate position of the Church in relation to "pagan" aspects of the feast. The Bishop responds by defining these aspects as pagan and folkloristic "dregs" that must be subdued by the hand of the Church; as was customary at the time, he also speaks about finding a "remedy" for this problem. However, the Bishop also acknowledges that the application of this "remedy" had been more potent than the evil itself, in that it succeeded only in provoking more intense expressions of "liberty" in the celebrations connected to the Gigli rather than achieving the desired effects. Indeed, the entire history of the feast revolves around an ongoing conflict between the expressions of the city and those of the ecclesiastical hierarchy. ${ }^{33}$

It is the second part of the documentary that according to my analysis has left such an indelible mark on the memory of Nolan residents. Specifically, the part residents remember the most is a scene where some local women are asked if their husbands found them more sexually exciting, and vice versa, during the feast period and if the Giglio was in some way reminiscent of a phallic symbol, etc. After all, until the 1970s it was not easy to ask such questions in Southern Italian contexts, especially in the kind of explicit manner the way the interviewer did in this documentary with the women who were dancing around the Gigli. Many Nolan locals perceived this attitude to be risqué because it seemed to characterize the feast in a way people did not agree with or, at any rate, alluded to characteristics that people did not wish to make public. Although it is currently included within the Catholic faith, some scholars believe that the Gigli feast (like many others in Italy and throughout the Mediterranean) is actually an altered reinterpretation of the ancient tree cult celebrated by Mediterranean agricultural societies, and thus should be understood within the context of springtime appeasement rites. ${ }^{34}$ Some Nolan locals were already opposed to this image of their feast, and when the video was released they sent letters to the RAI network criticizing the documentary and asking that it not be broadcasted on the national network. In the end, the video was not made public until two years later in the summer of 1982, when it was projected in Nola's 
central piazza; in this season, however, so many locals were on vacation that the city was nearly deserted and so only a few residents were able to attend the screening. The video only began to circulate many years later, when the first reproduction devices appeared in private homes and the use of video brought about a democratization process in the access to many documents.

Today, the documentary is easily accessible in that it can be found on several websites dedicated to the feast, ${ }^{35}$ and it is also widely present in many feast practitioners' private video libraries. Nonetheless, it is still rare for people to watch the final section because, although times have changed, many devotees still refuse to recognize the presence of those "allusions" to the sexual sphere (or phallic rites in general) in their feast.

To analyze this tendency to hide certain aspects of one's own culture from outsiders or to highlight certain aspects over others, I find it useful to draw on Herzfeld's notion of "cultural intimacy". In his work on nationalism and the Greek national character in particular (in relation to Italy, he speaks mainly of parochial characteristics), Herzfeld argues that every nation has its own stereotypes that the official culture tries to hide in order to manage its public image. When coming from the outside, these stereotypes are rejected in that they violate what Herzfeld defines as cultural intimacy, that is, the foundation of one's reassuring feeling of belonging to a community or, in his words, the recognition of those aspects of cultural identity that are considered embarrassing in the face of strangers, but which grant members the certainty of a shared sociality. We might therefore interpret the above-mentioned Nolan episodes as manifestations of cultural intimacy related to the local dimension, behaviors that the Nolan locals used to remove or hide certain aspects of their own culture that they did not wish to reveal to the outside in order to maintain their own "intimacy" while at the same time highlighting other more "comfortable" or less problematic aspects. This process was also visible in relation to the historical origins of the feast. ${ }^{36}$

38 Finally, several years ago, the video La Festa Felice was once again publicly screened during a conference in Nola. The film director was also invited, and he was impressed by how few criticisms he received from the Nolan audience. Of course this was due in part to the fact that only a few dozen people were in attendance, rather than all the families involved in the feast. In fact, it might have been interesting to show it to all of them and to observe their contemporary reactions. Even though almost thirty years had passed since the documentary was first released and today's cultural climate is much different than it was in the 1980s, and despite the overall emotional reaction of the public on recognizing some characters in the film who were since deceased, even on this occasion some audience members spoke up to criticize, once again, the scenes with the interviews that were considered most "uncomfortable".

Drawing on Carpitella, the well-known ethnomusicologist and founding father of Italian visual anthropology, we can even conceive of a comprehensive visual anthropology, a cinematographic study of cultural facts "beginning from film". In this sense film can be understood not simply as the appendix of work conducted in another setting, but rather as a product that can be used to concretely carry out scientific analyses. 


\section{Conclusion}

40 It is important here to underline that my visual work was also useful during the final phase of writing up my ethnographic monograph (currently still in progress) in that reviewing the numerous images I produced during my research, comprising approximately 200 hours of footage, aided me in revisiting specific festive moments so that I could better describe them in my writing. In this respect my videos were as, or even more, useful than my field notes.

On returning from my first ethnographic stay in New York in 2006, I produced an initial piece in 2007 based on my video recordings, in this case footage of the Gigli feast in the United States, for the Third edition of a National Video Competition called Memorie Migranti (Migrant Memories). This piece, called La Festa Migrante: I Gigli di Nola a New York (The Migrant Feast: Nolan Gigli in New York), ${ }^{37}$ was made using material shot in the field in 2006 edited together with a historical video document belonging to one of the families who had migrated to America, a family who had worked with me during my ethnographic research period.

This short video documents the family's trip back to Nola to watch the Gigli feast almost 60 years ago. Although this video recounts only a part of the work and does not display the best technical expertise, it has nonetheless become an important element of exchange and recognition, thus contributing to further reinforce my relations with my American informants and especially the family featured in the video. Their trust in me led them to hand over this never-before-published historical family video so that I could edit it together with footage of the contemporary feast, and this too is undoubtedly a result of the quality of the rapport I have been able to establish in the field.

In addition, this video also proved to be an opportunity to make Nolan locals aware of the festive events connected to the Gigli that have existed for over a century on the other side of the ocean and to further connect the various communities of practice associated with the Gigli feast.

As with "observational" cinema ${ }^{38}$, my first visual ethnographic product can be seen as an anti-metalinguistic product in the Wittgensteinian sense in that it seeks to "show" rather than "tell" ${ }^{39}$ In this way it privileges the direct presence of ethnographic reality over commentary and voice-overs, which are entirely absent from the video document. Furthermore, there are no interviews with practitioners and the editing, which has been entrusted to a technical professional, is designed to visually narrate the migration and juxtapose the two feasts in a way that highlights their similarities and differences. This was done in the effort to maintain a cinematographic gaze that was as faithful as possible to the reality under investigation, taking into account all the limitations imposed by archival documents and the resulting temporal gap characterizing the images that I decided to use in my case.

Besides a didactic application in university courses with my students over the years, my intent for the visual material I produced about the Gigli was to accompany the publication of my ethnographic monograph with a visual product that resembles a real ethnography documentary. In this case, the visual text is not meant to substitute for the written work of analysis on the subject but rather to accompany and strengthen the written text. The primary motivation for producing a documentary of this type originates in the ethical 
mandate to give some "result" back to the community that has collaborated in my ethnographic investigations over the years, be it written, textual or visual, often sharing thoughts and results ${ }^{40}$. In fact, the methodology I used is intended to fully respect the reciprocity between filming and filmed subjects, theoretically opening a space of video experimentation but also potentially sharing the video process with the community under investigation as I have done with other written texts produced so far about the feast. A further hypothetical development in this project could involve choosing a young Nolan Gigli practitioner to edit the document, someone who both has an insider's faze on the feast and is a professional video operator active in the local context. This figure, already introduced above, has worked a great deal on the feast and has often discussed with me the best way to shoot the Gigli during my research. I believe this collaboration would enable me to design a project that better corresponds to the internal logics of the community, but which might also facilitate dialogue and understanding about the scientific objectives that I have developed over years of analysis and observation of the festive institution. With this in mind, I conclude with a quote by Rouch:

...you can work for 15 days editing a film that lasts one hour. At this point, the film becomes a means of after-the-fact critical analysis of a ritual or technique; this way you can work with the people who are directly involved. This is truly irreplaceable

This article has demonstrated through concrete data acquired on an investigative field, how the choices of the visual ethnographer can assume a political value towards a democratization and a sharing of view on the local reality under investigation. As a matter of fact, my thesis - still in process - aims to show collaboration between researcher and research subjects produces a work that is the result of a polyphony of voices in the anthropological science. In other words, a modality of orienting the observation and the local memory through the audiovisual devices used by the researcher in a participatory manner as for of the views and the practices of the investigated subjects themselves, accustomed to an iper-mediatized society and therefore particularly sensitive to the value of their visual dimension and their culture.

Being within a field of investigation can mean firstly "to learn to watch like" the protagonists of that field watch and the practice of the watching again with them can become an effective methodology to raise specific questions, otherwise invisible to the classic practice of the participant observation.

The videocamera can represent the common ground on which to experiment thoughts and viewpoints, external and internal to the community, and it can even result into a transversal language to the writing and to the verbal communication since visual products have, in contemporary mediatic society, a prominent role. They represent the starting point for thinking critically of an anthropology that aims to analysis societies and their practices as being both polyphonic and dynamic. 
Figure 1 : Gigli with the musical division, during the Nolan Gigli Feast, June [?] 2011

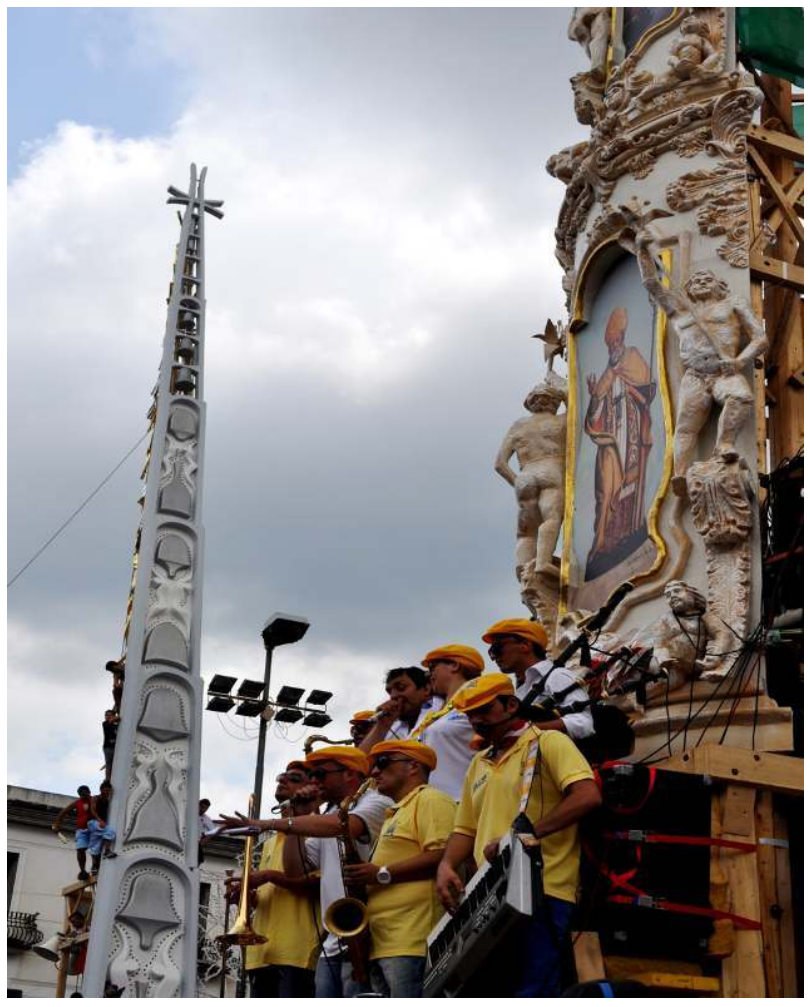

Photo by Sabrina Iorio 
FIgURE 2 : THE FANTASTIC TEAM PARANZA CARRIES THE GIgLIO THROUgH THE CROWD, NOLAN GIgLI FEAST 2011

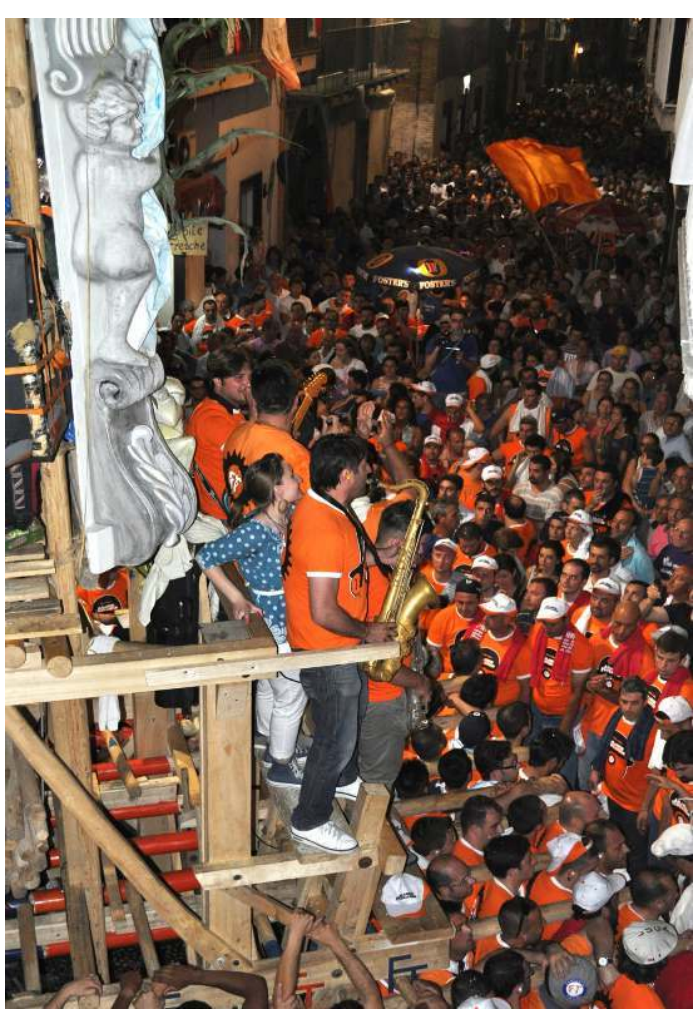

Photo by Sabrina Iorio 
Figure 3 : THE "FT" PARANZA CARRIES A gIgLIO, NOLAN GIgLI fEASt 2011

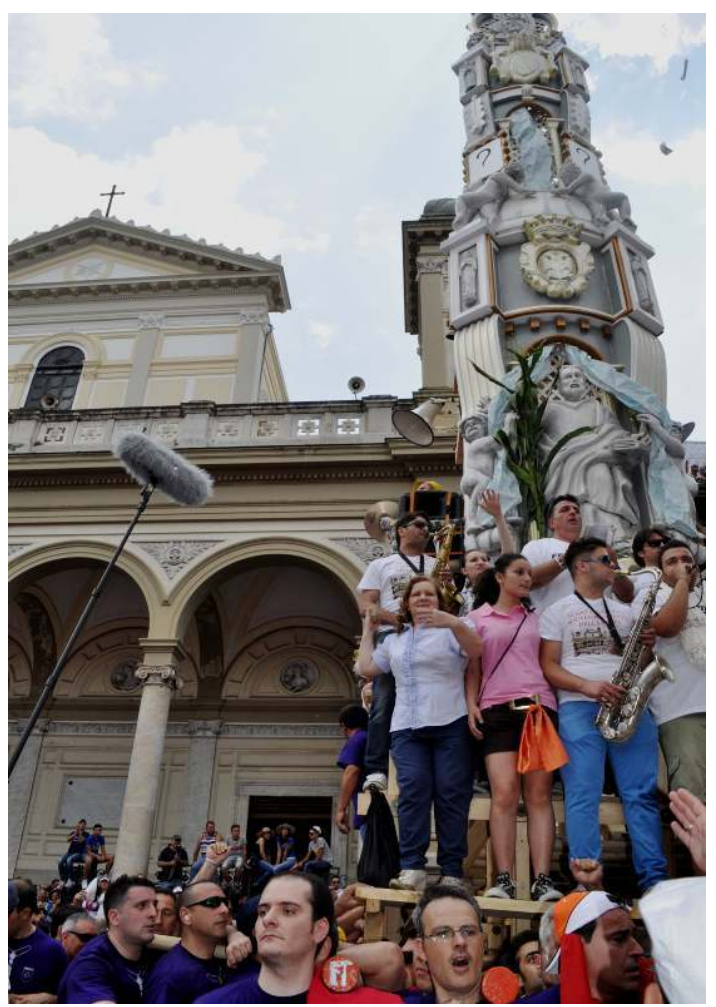

PHOTO BY SABRINA IORIO

THE ETHNOgRAPHER SHOOTS THE GIgLIO AS IT "DANCES", NOLAN GIgLI FEAST 2011

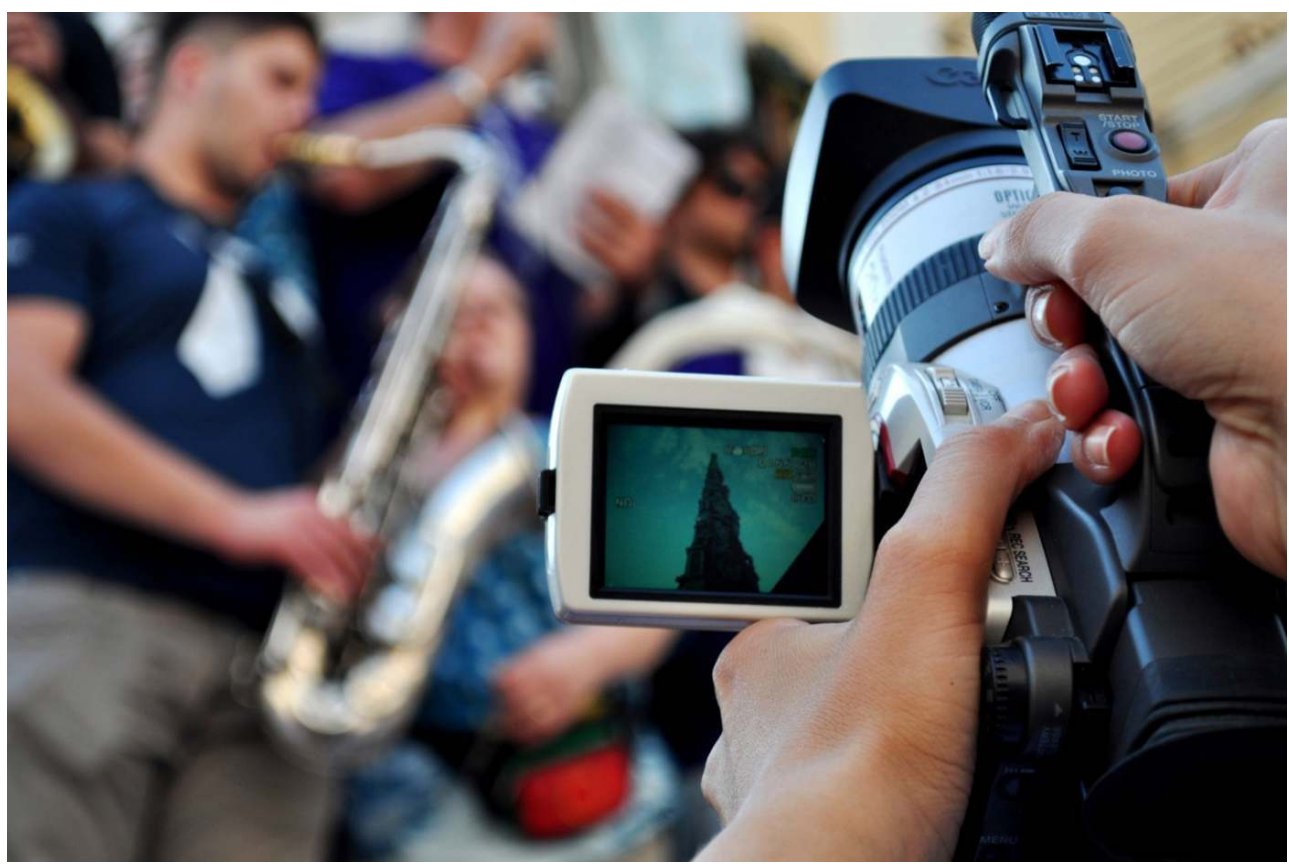

PHOTO BY SABRINA IORIO 


\section{AN "AVATAR LIfTER" ADMIRES A GIgLIO BUILT ON THE WEB,}

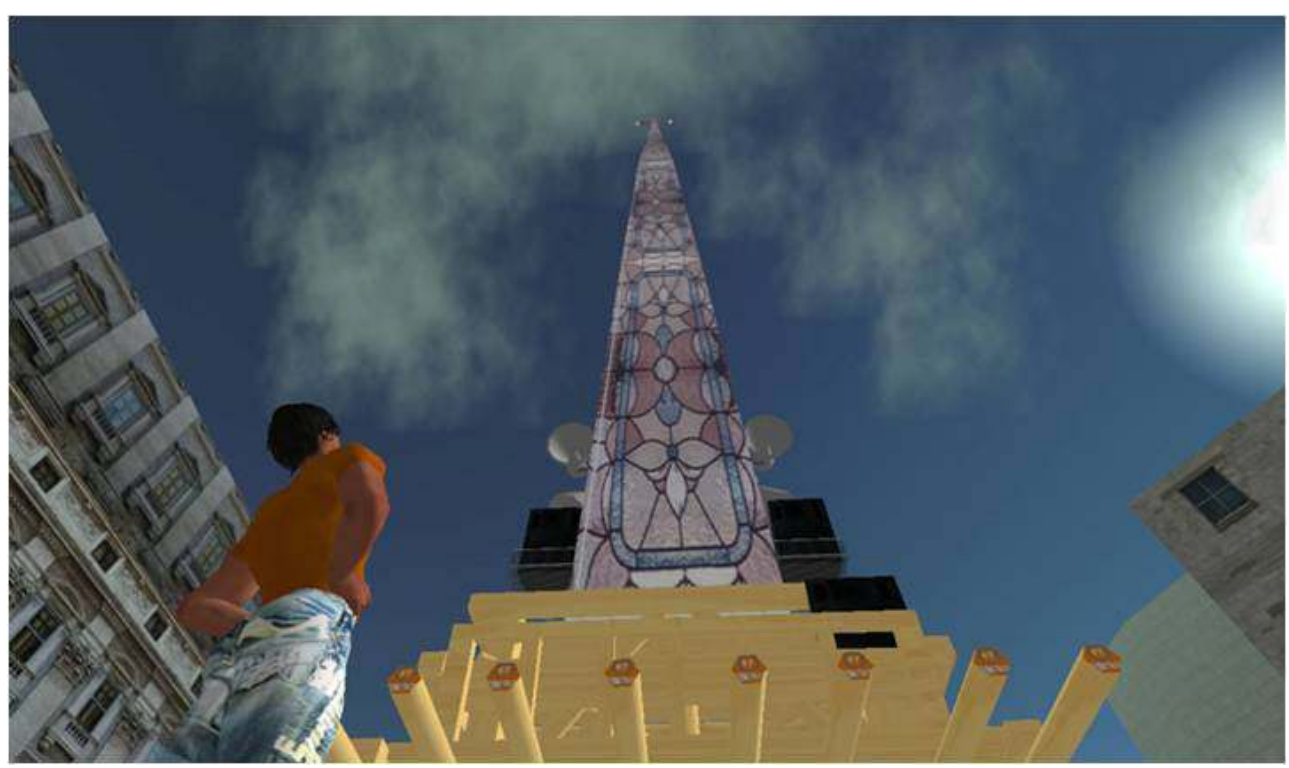

IMAgE EXTRACTED FROM SECOND LIFE, 2008

\section{BIBLIOGRAPHY}

Avella L., La festa dei gigli, Scala, Nola, 1993.

Augé, M. and Colleyn, J.P., The World of the Anthropologist, Berg, Oxford, 2006

Ballacchino K., "Il Giglio di Nola a New York. Uno sguardo etnografico sulla festa e i suoi protagonisti”, in Tirabassi M. (ed) Atti del Convegno internazionale Con gli occhi della globalizzazione. I nuovi studiosi e la ricerca delle migrazioni italiane, Altreitalie. Rivista Internazionale di studi sulle migrazioni italiane nel mondo, Centro Altreitalie, Edizioni della Fondazione Giovanni Agnelli, Torino, n. 36-37, Gennaio-Dicembre 2008, pp. 275-289

Ballacchino K., "Embodying devotion, embodying passion. The Italian tradition of the festa dei Gigli in Nola", in Encounters of body and soul in contemporary religiosity. Anthropological reflections, Fedele A. and Blanes R. L. (eds), Berghahn Books, Oxford - New York, 2011

Banks M. and Ruby J. (eds), Made do Be Seen. Perspecitves on the History of Visual Anthropology, University of Chicago Press, 2011

Bindi L., "Il corpo folklorico. Strategie dello sguardo, media e località", in A.A. (eds.), Il tessuto del mondo, Rubbettino, Soneria Mannelli, 2008

Bindi L., “'Folklore' virtuale. Note preliminari a un'etnografia delle tradizioni sul web”, La ricerca folklorica, n. 57, 2008

Bindi L., "Imaginar un paìs", in Gazeta de Antropologìa de l'Universidad de Granada, II/2008 
Blank Trevor J., Folklore and the Internet: Vernacular Expression in a Digital World, All USU Press Publications, 2009, Paper 35, http://digitalcommons.usu.edu/usupress_pubs/35

Brown J.S. and Duguid P., "Organizational Learning and Communities of Practice: Toward a unified view of working, learning and innovation", Organization Science, 2, no. 1, 1991., pp. 40-57

Busoni M., I ritmi della memoria. Conversazioni sul lavoro con i carpentieri navali a Limite sull'Arno, Centro Editoriale Toscano, Firenze, 1996

Ceparano F., (ed) Per una filmografia dei Gigli di Nola, Extra Moenia, Tipografia Scala, Nola, 2009

Chaiklin S. and Lave J., (eds) Understanding practice. Perspectives on activity and context, Cambridge University Press, Cambridge, 1993

Chiozzi P., Manuale di Antropologia Visuale, Edizioni UNICOPLI, Milano, 2000

De France C., "I fondamenti di un'antropologia filmica”, La Ricerca Folklorica n. 3, 1981, pp. 51-58

Guindi F. E., Visual Anthropology: Essential Method and Theory, Walnut Creek, CA: AltaMira Press, 2004

Faeta F., "Ernesto de Martino e l'etnografia visiva. Appunti per la definizione di un percorso critico", in Ossimori, 7, 1995

Faeta F., Strategie dell'occhio. Saggi di etnografia visiva, Franco Angeli, Milano, 2003

Freedberg D., Il potere delle immagini, Einaudi, Torino, 1993

Gatewood J. B. “Actions speak louder than words”, in Dougherty J. W. (ed), Directions in cognitive anthropology, University of Illinois Press, Chicago, 1985

Gigliotti L., I Gigli di Nola, Video/Italia, 1990

Goffman E., Interaction Ritual: Essays in Face-to-Face Behavior, Aldine, Chicago, 1967.

Goodwin C., "Professional Vision", American Anthropologist n. 96 (3), 1994, pp. 606-633

Grasseni C., "Il video documentario come rappresentazione etnografica di comunità di pratica", in Manoukian S., (ed), Etno-Grafie: Testi - Oggetti - Immagini, Meltemi, Roma, 2003, pp.147-171

Grasseni C., "Video and ethnographic knowledge: skilled vision in the practice of breeding", in Pink S., Kurti L. and Afonso A. I., (eds.), Working Images, Routledge, London, 2003

Pink S., Kurti L. and Afonso A. I., (eds.), Lo sguardo della mano. Pratiche della località e antropologia della visione in una comunità montana, Bergamo University Press, Bergamo, 2003

Pink S., Kurti L. and Afonso A. I., (eds.) and Ronzon F., Pratiche e cognizione. Note di ecologia della cultura, Meltemi, Roma, 2004

Pink S., Kurti L. and Afonso A. I., (eds.), (ed) Skilled Visions. Between apprenticeship and standards, Berghahn, Oxford, 2007

Pink S., Kurti L. and Afonso A. I., (eds.) , (ed) Imparare a Guardare. Sapienza ed esperienza della visione , Franco Angeli, Milano, 2008

Grimshaw A. and Ravetz A., Visualizing Anthropology, Bristol, UK; Portland, OR: Intellect, 2005

Henley P., The Adventure of the Real. Jean Rouch and the Craft of Ethnographic Cinema, Chicago University Press, 2010

Herzfeld M., Intimità culturale. Antropologia e nazionalismo, L'Ancora del Mediterraneo, Napoli, 2003 (ed. or. 1996).

Lave J. and Wenger E., Cognition in Practice, Cambridge University Press, New York, 1988. 
Lave J. and Wenger E., Situated Learning: Legitimate Peripheral Participation, Cambridge University Press, New York, 1991

Leroi-Gourhan A., Le geste et la parole, Editions Albin Michel, 1965

MacDougall D., "Beyond observational cinema", in Hockings P., (ed), Principles of visual, 1975

MacDougall D., "The visual in anthropology”, in Banks M. and Morphy H., (eds), Rethinking Visual Anthropology, Yale University Press, New Haven, 1997

MacDougall D., The Corporeal Image: Film, Ethnography, and the Senses, Princeton, NJ: Princeton University Press, 2006

Manganelli F., La festa infelice, LER, Napoli, 1973

Marano F., Camera etnografica. Storie e teorie di antropologia visuale, Franco Angeli, Milano, 2007

Marano F., Il film etnografico in Italia. Rapporti fra etnografia e film in Italia, Edizioni di Pagina, Bari, 2007

Marazzi A., "Visual Anthropology in a World of Images", Visual Anthropology, vol. 12, 1999

Marcus G. E., "Ethnography in/of the World System: The Emergence of Multi-Sited

Ethnography", in Annual Review of Anthropology, Vol. 24, 1995, pp. 95-117

Mazzacane L., "Sull'uso dei mezzi audiovisivi”, in Critica Sociologica, 1977, pp. 39-40

Mirzoeff N., Introduzione alla cultura visuale, Meltemi, Roma, 2002

Palmieri G., La Festa Felice, RAI, 1980

Pink S., The Future of Visual Anthropology: Engaging the Senses, London, England; New York, NY: Routledge, 2006

Pink S., Doing Visual Ethnography: Images, Media and Representation in Research, Sage, London, 2007

Pink S., Visual Interventions. Applied visual Anthropology, Berg, Oxford, 2007

Posen S.I. and Ward D. F., "Watts Towers and the Giglio Tradition", Folklife Annual, DC: Library of Congress, Washington, 1985, pp. 142-157.

Posen S.I. and Ward D. F., "Storing Contexts: The Brooklyn Giglio as Folk Art", in Vlach J. M., Bronner S. J., (eds), Folk Art and Art Worlds, UMI Research Press, Michigan, 1986, pp. 171-91.

Posen S.I. and Ward D. F., Sciorra J., Cooper M., “Brooklyn's Dancing Tower: Brought to America by Immigrants from an Italian Town, the Feast of Saint Paulinus Celebrates Religious Devotion, Community Ties, and the Ideals of Manhood", Natural History, Vol. 92, N. 6, June 1983, pp. 30-37.

Riccio B., "Esplorare spazi translocali. Riflessioni sull'etnografia multi-situata nello studio dei processi migratori", in Benadusi M., (ed) Dislocare l'antropologia. Connessioni disciplinari e nuovi spazi epistemologici, Guaraldi, Rimini, 2006, pp. 133 - 153

Rouch J., "Etnografia e cinema", La Ricerca Folklorica n. 3, 1981, pp. 41-46

Sciorra J., “'O' Giglio e Paradiso': Celebration and Identity in an Urban Ethnic Community”, in Celebrating the City, Urban Resources, Vol. 5, N. 3, 15-20, Spring 1989, pp. 44-46.

Sciorra J., "Summer spirit of giglio: A brief history of the giglio feast in Italy and America", America and Italia Review 1, Available from americaitaliareview.com; INTERNET, 2003.

Wenger E., McDermott R. and Snyder W.M., Cultivating Communities of Practice. A guide to managing knowledge, Harvard Business School Press, Boston, 2002 
Wenger E., Communities of practice: learning, meaning and identity, Cambridge University Press, Cambridge, 1998

\section{NOTES}

1. This process is influenced by the criteria that J. Rouch used to define his "participating camera" or by some modalities similar to what de France called "ethno-dialogue" referring to the relationship between the anthropologist and the objects of the research, in an "exploratory" filmic anthropology.

2. Cfr. Grimshaw and Ravetz 2005

3. For a general treatment of visual anthropology in Italy, some the main references can be: Faeta, 1995; Id, 2003; Marazzi, 1999; Mazzacane, 1977; Chiozzi, 2000. On the international debate the following contributions: Mirzoeff, 2002; the works of Pink; Guindi 2004; MacDougall, 2006; Banks and Ruby 2011.

4. For a general treatment of the issues relating to video as an instrument of analysis of communities of practice, see among may, some of the contributions of Grasseni, 2003 and 2008.

5. La paranza is a hierarchic structure of about 128 men, called "collatori", hired every year to simultaneously lift the Giglio on their shoulders through wooden beams called "varre" or "varritielli", connected at the base of the wooden machine. Specific melodies composed for the occasion accompany the collective transportation of the Giglio, to assist the orders of the "capoparanza" and make the obelisk dance. The musical division places itself on the base of the festive machine, causinf each obelisk to weight about 40 quintals.

6. According to legend, the Nolans greeted their bishop Ponzio Anicio Meropio Paolino of Bordeaux (355-431) with the "Gigli" (lilies), on his return by ship. Over the centuries these flowers have grown in size, in proportion to the growth of devotion for the Saint, until reaching their present structure and height. For a general approach to the Gigli Feast in Nola see: Manganelli 1973; Avella 1993.

7. See futher Sciorra, 1989; Id., 2003; Posen, Ward, 1985; Posen 1986; Posen, Sciorra, Cooper, 1983 and Ballacchino 2008.

8. See Herzfeld, 2003 (1996).

9. Regarding "communities of practice" see: Goffman 1967; Brown and Duguid 1991; Lave and Wenger 1991; Chaiklin and Lave 1993; Lave and Wenger 1988; Wenger 1998; Grasseni and Ronzon 2004; Wenger, McDermott and Snyder 2002.

10. Regarding folklore and the virtual world, see the following contributions: Bindi 2008, 2008, 2008; and Blank, Trevor 2009.

11. Wenger, 1998.

12. See Lave and Wenger 1991.

13. Chaiklin and Lave 1993

14. Multi-sited ethnographic research originated in the 1980 s and was employed in interdisciplinary studies such as media studies, social and cultural of science and technology, and cultural studies. For a deeper analysis of the central issues of a multi-sited ethnographic approach, see Riccio 2006.

15. Leroi-Gourhan 1965, Busoni 1996.

16. See Grasseni 2007.

17. See de France 1981, p. 53.

18. See the interesting contributions of Pink: 2006, 2007, 2007.

19. During the 1990s, the rising popularity of lightweight video cameras stimulated the production of ethnographic representations and self-representations of local identity. The old and expensive Super 8 film was replaced by the magnetic tape, which lasted longer and cost less. 
With the advent of videotapes, family and touristic videos proliferated and groups' "autoethnographies" increased in number. See Marano 2007.

20. For a complete analysis of Rouch's filmography see Hanley 2010.

21. The festive pathway includes various extremely difficult spots where the different paranzas compete in terms of strength and ability in carrying the obelisk. One of these spots is called "vico Piciocchi". This alley is located at the end of the Gigli path and is so narrow that the Giglio cannot pass though it with the mobile lateral wooden beams, usually supported by the tallest bearers in order to evenly distribute the lateral weight of the festive machine. The passage of the Giglio though this spot is thus particularly laborious because the paranza carrying the machine is required to halve itself and the obelisk must be carried quickly and steadily to avoid becoming unbalanced and getting stuck on the buildings on either side, as often occurs.

22. Rouch 1981, p. 44.

23. de France 1981, p. 56.

24. About the role of the body in the feast and its "embodiment" I would like to reference one of my recent contributions: Ballacchino 2011.

25. Grasseni 2003, p. 7.

26. There is also a channel of the "paranza" on which I worked, called "FT channel", where the web tv of the Gigli of Nola feast is broadcasted 24 hours. On this channel, for two years in a row, it has been shared with the researcher to broadcast my filmed material of the feast has been shared, as they were considered by many the best ones.

27. For a more in-depth understanding of the role of images in emotional and non-emotional terms, a fundamental text is Freedberg 1993.

28. This expression means to pretend that the Giglio is there, therefore waving arms as to imitate the act of "collare" under an imaginary "varra" or carrying a person as if it was a Giglio.

29. This title was most likely used to counterbalance a previously published volume, see Manganelli 1973. The documentary was produced in consultation with Vincenzo Bo, Domenico de Masi and Lello Mazzacane and with the collaboration of Manganelli himself, the author of the abovementioned text.

30. There are many examples, but one interesting documentary is Gigliotti L., I Gigli di Nola, 1990, produced by Video/Italia for the Cultural Heritage Ministry as part of the series "Il Folklore-un bene culturale vivo" (Folklore: a live cultural heritage). The famous Italian ethnomusicologist Diego Carpitella was on the scientific advisory board for this project. For an overall review of the feast filmography, see Ceparano 2009.

31. About the history of the feast, there is also an interesting visual project carried out by the anthropologist Lello Mazzacane in 1975. Called Multivision, this multimedia piece was very innovative for the time, employing 12 slide projectors arranged as overhead projectors to display images of the feast onto a big screen. This document is less well-known in the Nolan collective memory, probably because Multivision was not, for obvious reasons, an easily accessible product and therefore was not reproducible on a daily basis, in contrast to the numerous VHS and DVDs produced subsequently.

32. The same thing also happened to me although in a different way, when at the beginning of my research all the Nolan locals took it for granted that I should be directed to concentrate my investigation on certain groups of Gigli bearers who were considered the most "famous" or "strongest" groups on the Gigli scene.

33. The city of Nola is a diocese and thus has hosted a Bishop's office since the middle of the Third Century a.d., which demonstrates a secular and very strong presence of Catholic power. Following criticisms made by various sitting Bishops over the years, there have been efforts to eliminate many pre-Christian aspects of the feast (those considered more problematic), but without much success. 
34. According to some interpretations, the origins of the feast lie in a Christian reinterpretation of a celebration that was based on pre-Christian fertility rituals.

35. The document may be viewed online (although in a very low resolution form) in the video section of the website by the Nolan paranza I worked with, the Fantastic Team. See http:// www.fantasticteam.it/PRIMAPAGINA.htm

36. During the last six years of my ethnographic research, I happened to witness allusions made to the sexual sphere in reference to the Gigli and their movements many times, especially by some of the youngest practitioners.

37. Also in this case the documentary is online in the video section of the Fantastic Team website, see http://www.fantasticteam.it/PRIMAPAGINA.htm

38. MacDougall 1975 and 1997.

39. Grasseni 2003.

40. For further discussion of the issue of ethnographic documentary production, see some studies primarily referencing the Italian context: Marano 2007 and 2007; Faeta 2003

41. Rouch 1981, p. 41.

\section{ABSTRACTS}

Drawing on research carried out between 2006 and 2011, this article argues for the centrality of the ethnographic work in the investigation of the most innovative field for contemporary anthropology: visual culture. The original characteristics of the Gigli., a one hundred year-old feast encourages the author to think in visual anthropological terms, and to propose an hypothesis about the potential of the visual as a methodology and metaphor of anthropology. Based on concrete ethnographic examples, the article presents communal ritual practice through three visual dimensions: as a methodological and knowledge-producing practice of investigation, as the object and source of the research itself and, lastly, the visual document as a potential product of ethnography alongside the written text. Therefore this article will try to answer some questions in anthropological literature about visual apprenticeship and the methodological role of the participant observation.

À partir des enquêtes de terrain menées entre 2006 et 2011, cet article défend l'importance du travail ethnographique au sein d'un des champs disciplinaires les plus innovants en anthropologie du contemporain: la culture visuelle. Les caractéristiques premières du rituel Gligli, fête existant depuis une centaine d'années, permettent à l'auteur de concevoir une pensée visuelle et anthropologique et de proposer une hypothèse construite sur le potentiel du visuel comme méthode et métaphore du champ anthropologique. Fondé sur des exemples ethnographiques concrets, ce travail présente une pratique rituelle collective à partir de trois fonctions $\mathrm{du}$ visuel : une méthode et une pratique productrice de connaissance, un objet à l'origine de la recherche elle-même et enfin des documents visuels, productions ethnographiques potentielles qui accompagnent le texte écrit. Cette recherche tente de répondre à certaines des questions posées par les contributions anthropologiques de références concernant l'apprentissage de l'utilisation du visuel (de l'image) et l'observation participante comme méthode potentielle. 
Basado en investigaciones realizadas entre 2006 y 2011, este artículo defiende la centralidad del trabajo etnográfico en la investigación del campo más innovador de la antropología contemporánea: la cultura visual. Las características originales del Gigli, una festividad de 100 años de antigüedad, lleva el autor a hacer una reflexión antropológica en términos visuales, y proponer una hipótesis sobre el potencial de lo visual como metodología y metáfora de la antropología. A partir de casos etnográficos concretos, el presente artículo analiza una práctica ritual colectiva mediante tres dimensiones de lo visual : lo visual como práctica metodológica generadora de conocimiento, lo visual como objeto y fuente de la investigación, y, finalmente, el documento visual como resultado potencial de la etnografía, conjuntamente con el texto escrito. Así pues, este artículo intentará responder a algunas problemáticas de la literatura antropológica sobre el aprendizaje visual y el rol metodológico de la observación participante.

\section{INDEX}

Keywords: visual ethnography, visual culture, communal ritual practice, visual methodology Introduction

Palabras claves: etnografía visual, cultura visual, ritual colectivo, metodología visual Mots-clés: ethnographie visuelle, culture visuelle, rituel collectif, visuel et méthodologie

\section{AUTHOR}

\section{KATIA BALLACCHINO}

University of Rome "Sapienza" and University of Molise 